\title{
FDI Inflow Activities and Ghanaian SMEs Strategic Decision-Making Process: Mediating Role of Interfirm Value Co-Creation
}

\author{
Joseph Asante Darkwah ${ }^{1,2 *}$, Cephas Paa Kwasi Coffie ${ }^{2,3}$, Samuel Antwi ${ }^{4}$ \\ ${ }^{1}$ School of Finance, Zhejiang Gongshang University, Hangzhou, China \\ ${ }^{2}$ All Nations University, Koforidua, Ghana \\ ${ }^{3}$ School of Management and Economics, University of Electronic Science and Technology of China, Chengdu, China \\ ${ }^{4}$ School of Management and E-Business, Zhejiang Gongshang University, Hangzhou, China \\ Email: ^darkwahasante@gmail.com, coffiecephas@gmail.com, samantwi88@outlook.com
}

How to cite this paper: Darkwah, J.A., Coffie, C.P.K. and Antwi, S. (2021) FDI Inflow Activities and Ghanaian SMEs Strategic Decision-Making Process: Mediating Role of Interfirm Value Co-Creation. Open Access Library Journal, 8: e7567. https://doi.org/10.4236/oalib.1107567

Received: May 22, 2021

Accepted: July 25, 2021

Published: July 28, 2021

Copyright $\odot 2021$ by author(s) and Open Access Library Inc.

This work is licensed under the Creative Commons Attribution International License (CC BY 4.0).

http://creativecommons.org/licenses/by/4.0/ (c) ${ }_{\mathrm{By}}$ Open Access

\begin{abstract}
Foreign direct investment (FDI) inflow activities are seen as a threat to the survival of resource-constrained SMEs in Ghana. Hence, this preconception stifles collaborations between foreign and local businesses. Therefore, to justify the need for such collaborations, we estimate the relationship between FDI inflow activities and SMEs' strategic decision making as well as the mediating role of interfirm value co-creation using the structural equation model. Using data survey responses of 856 Ghanaian SMEs, we find positive significant relationships between FDI inflow activities, environmental sustainability decisions, economic sustainability decisions, and social sustainability decisions. Further, interfirm value co-creation mediates the positive relationship between FDI inflow activities and economic sustainability decisions. So, SMEs should embrace FDI inflow activities in the country and create knowledge from the technology and human expertise of these businesses. Again, policymakers should devise forward-thinking strategies to stimulate an information-sharing ecosystem promoting collaboration between domestic and foreign-owned businesses in Ghana.
\end{abstract}

\section{Subject Areas}

Management

\section{Keywords}

FDI Inflow Activities, Interfirm Value Co-Creation, SMEs, Decision Making, Ghana 


\section{Introduction}

SMEs in Ghana occupies a significant position in the industrial landscape of the country. Statistically, SMEs top more than $90 \%$ of the total businesses [1]. Consequently, the employment and revenue generation prowess of these classes of businesses cannot go under the radar. However, these businesses have identified challenges (lack of financial resources, managerial inefficiencies, and unfair competition from foreign firms) stifling and threatening productivity and their long-run survival [2] [3]. While financial and managerial constraints have received much research attention, unfair competition from foreign firms has minimal inquisition [4]. Often, existing studies cite mainly the negative effects of foreign businesses on SMEs in the country [5] [6]. However, SMEs can strategically benefit from the influx of foreign companies in the country like in China and the United States [7]. This raises unanswered questions about the effect of foreign direct investment (FDI) inflow on SMEs in Ghana.

FDI is a business venture undertaken by organizations or individuals in another economy and this could be classified as outflow or an inflow [8]. While the former focuses on investments moving out, the latter focuses on investments coming into a host country [9]. Between the years 2000 and 2016, world FDI inflows amounted to an annual average of 1.28 trillion U.S. dollars, which matches a ratio of $2.3 \%$ relative to world GDP (UNCTAD, 2018). Documented by scholars, FDI increases economic growth and creates employment in the host nation [10] [11]. FDI advances the economic development of a host economy by augmenting the available supply of technology, capital, and entry to overseas markets. Despite this, Ghanaian SMEs constantly resist the influx of foreign companies [10]. This is because the managerial inefficiencies and the lack of financial resources create unfair competition. Further, SMEs are unable to create value through the expertise imparted by these foreign-owned businesses [11]. This stifles growth in the industry and limits the creativity of SMEs.

The sustainability of SMEs depends on long-term strategy and innovation capability [12] [13]. Further, SMEs' decision-making is influenced by both internal and external environmental [14]. This emphasizes FDI inflow activities as a significant external environmental factor for SMEs. Hence, the inability of SMEs to generate adequate external information from these sources could hinder economic, social, and environmental decisions.

Despite the potential benefits of FDI inflow activities, studies focus mainly on the perceived limitations in Ghana [15] [16] [17]. This creates policy narrowmindedness requiring research inquisition. Consequently, we explore the relationship between FDI inflow activities and strategic decision-making choices of SMEs in Ghana. Specifically, we seek answers to these questions: what is the relationship between FDI inflow activities and the environmental, economic, and social sustainability decisions of SMEs in Ghana? And what is the role of interfirm value co-creation decisions in the relationship between FDI inflow activities and these decisions? The sustainability decisions of SMEs capture activities of 
SMEs to protect the environment, activities to improve the profitability of the business, and activities to improve the welfare of employees. Empirically, innovation reduces energy consumption and carbon emission [11]. Further, innovation improves efficiency and productivity [7]. To achieve these, a business strategy like interfirm value co-creation is pivotal [18]. Interfirm value co-creation is a deliberate act to create value in terms of products, services, or processes by engaging actors within a specific ecosystem [19]. This is evidenced to improve the profitability of SMEs in Ghana [20]. Thus, FDI inflow activities could stimulate interfirm value co-creation decisions [21] because SMEs benefit from the superior technology, strategy, and infrastructural offerings of these firms.

Using data from the survey response of 856 SMEs in a structural equation modeling (SEM), we find a positive relationship between FDI inflow activities, environmental, economic, and social sustainability decisions of SMEs in Ghana. Further, we ascertain that interfirm value co-creation decisions strengthen the positive relationships between the variables. Therefore, this outcome is significant to SMEs, policymakers, and industry practitioners. This challenges SMEs to invest in improved technologies to explore possible collaborations with foreign businesses. This contributes to the literature by highlighting the significance of FDI to SMEs' sustainability in the country. Policymakers can devise forward-thinking strategies to stimulate collaborations between domestic and foreign-owned businesses. Specifically, the government can provide subsidies or incentives for foreign businesses collaborating with local SMEs. Further, studies can explore the possible collaboration modes, challenges, and prospects of FDI in Ghana.

The remainder of the paper is organized as follows; literature review and formulation of hypothesis, explanation of the adopted research methods for the conduct of the study and model development, data analysis, presentation, and the discussion of the results from the analysis and the provision of suitable recommendation for policymakers and future studies.

\section{State of the Art and Hypothesis Development}

This section discusses the literature on FDI inflow activities, the sustainability of SMEs in Ghana, and interfirm value co-creation. Further, based on the literature we develop hypotheses for the study accordingly.

\subsection{FDI Inflow Activities}

FDI inflow activities in Ghana promote economic growth and development, also, boosts capital formation, and enhance the quality of capital stock in the country. Studies show FDI inflow activities into Ghana predominantly come from China, the USA, India, and South Africa which contributes more to the Agriculture, Manufacturing, Building/Construction, and Service sectors of Ghana [22]. All this diverse inflow of funds impacts different sectors of the economy but in the long run, creates jobs and contributes to economic growth. In the agriculture sector, for instance, FDI involvement has reduced unemployment and augmented the production of primary products for local consumption as 
well as exports which have positively influenced the economic growth of Ghana [21]. The financial sector also received a lot of improvement in services by the influx of foreign banks and this created a platform for local Banks to mimic, at the end, FDI positively influenced the profitability of commercial banks in Ghana [23]. Literature attests to the fact that FDI impacts the nation Ghana positively and adds to the economic growth and social well-being of its populist. The question, therefore, is what influences FDI inflow activities into Ghana? Most research points to variables like tax incentives, exchange rates, labor cost, and political stability among others.

The factors motivating massive investment (FDI) in countries might not necessarily differ in entirety as one move from one region to the other and especially when countries are in the same economic zone. In support, factors influencing FDI in Bangladesh and Malaysia are similar to those in Ethiopia. FDI inflow activities in Bangladesh from 2000 to 2014 had a positive correlation with the GDP, Inflation, Infrastructure, Labor cost productivity, Trade openness, and Trade performance [24]. And on the other hand, Ali [25] investigates the significant motives of inward FDI to Ethiopia from 1992-2015 and concludes there is a positive and significant relationship between FDI and market size, trade openness, exchange rate, and financial freedom. Again, in Malaysia exchange rates, gross domestic product, broadest money supply, and trade openness had a positive impact on FDI inflow activities [26]. In Ghana, however, the regulatory framework for FDI operations and other government policies are believed to play a significant role in FDI inflow activities [27]. Studies also show both long and short-run existence of significant negative effects of inflation rate, exchange rate and interest rate on FDI operations in Ghana, however gross domestic product (GDP), electricity production, and telephone usage had a positive effect on FDI [5].

Other findings suggest infrastructural development and natural resources as key drivers or indicators of FDI inflow activities in Ghana, other variables like the lending interest rate, market size, and GDP growth rate also significantly influence FDI inflow activities in Ghana [28]. Corporate tax was also found to have a significant negative impact on FDI inflow activities in Ghana in the short-run but it turns to positively influence FDI inflow activities in the long-run [9]. Population health, a factor neglected by most researchers to ascertain whether it significantly influence FDI inflow activities. The study is the first to employ infant mortality rate, under-five mortality rate, and death rate in examining the effect of population health on FDI inflow activities. It however documents that population health significantly influences FDI inflow activities to Ghana [29]. In summary, factors influencing FDI inflow activities in Ghana include market size, government regulations, natural resources, population health, infrastructure, exchange and interest rates, etc.

\subsection{Sustainability of SMSs}

It is documented, the role SMEs play in the various countries they situated by 
reducing unemployment and adding to Gross Domestic Product (GDP) [30] [31]. In most countries, SMEs are believed to contribute about 50\% of GDP [32]. The operations of these SMEs are however always under pressure either from internal or external factors like FDI. Because most SMEs might not be able to compete with these MNCs, our argument is for them to foster a link or collaboration through which knowledge and technical know-how could be easily transferred. This is one way or the other will help to employ new technology and way of doing things that will be more profitable as well as environmentally friendly. Sustainability-oriented innovation, which shows an objective to cultivate a product or service that bestows social, economic, and environmental sustainability, has gained growing institutional and academic attention, for the reason that innovation is an indispensable part of accomplishing sustainability [33]. For this reason, governments across the globe have been dedicated to sustainable or maintainable development as a policy goal. This has been buttressed by a lot of new ideas and policies extending from international agreements to national policy frameworks, environmental laws, regional programs, and local strategies [34]. In light of this, Sarkodie and Strezov [35] suggest that FDI inflow activities with modernized clean technological transfer and enhancement in labor and environmental management practices could assist emerging economies to realize sustainable development goals. The question then, is, do FDI inflow activities contribute positively or negatively to the sustainability of these SMEs operations as well as the environment in which they operate?

As stated earlier, a way out of the friction between SMEs and FDIs concerning market space and sustainable economic, social and environmental well-being is through collaborations, mergers. Havierniková and Kordoš [36] argues that one form of contemporary entrepreneurship that could assist SMEs' sustainability in the environment in which they operate is cluster cooperation. This type of entrepreneurship brings many positive effects. The power of collaborations influences not just the operations of both businesses but it gives room for best practices to be learned and shared among participants. In Nigeria for instance, Babatunde et al. [37] found improvement in labor quality as a result of FDI inflow activities to the nation which in the long-run positively influenced GDP. It is also important to note that, technology transfer between FDI firms and young SMEs, direct linkages, and the interactions between them cause SMEs to conduct $\mathrm{R} \& \mathrm{D}$ strategies in the supply chain which is obtained through direct transfer of technology between connected firms [38]. Knowledge transfer is an important component to factor into the link between FDI and host SMEs. However, in many cases, there are hindrances to the effective transfer of technology and knowledge. Pham and Dinh [32] analyzed the linkage with FDI and SME operations in Vietnam and how effective knowledge is being transferred from the collaborations.

Findings point to the fact that three factors had a significant impact on the effectiveness of knowledge transfer, including the Language ability of foreign 
managers, Cultural openness, and Communication distance. These factors when managed well positively impact the transfer of knowledge. In Macao, the emergence of investments by MNCs brought favorable and unfavorable effects to local SMEs. Host SMEs were challenged in terms of employing and retaining human resources, given the eye-catching salaries and benefits, and training offered by MNCs. The solution adopted for SMEs sustainability, however, was collaborating with MNCs as it serves as important partners in networking [39]. This re-affirms the point that the internationalization process and enterprise networks are positively related to refining corporate sustainability, which promotes labor productivity [40]. Does an increase in FDI significantly mean an increase in economic or social sustainability? Bokpin [41] researches foreign direct investment and environmental sustainability in Africa and concludes that an increase in FDI inflow activities significantly increases environmental degradation and recommends governments in African to develop tighter policies and measures to curb the problem. The decline of carbon dioxide emissions in developed countries can be attributed to a paradigm shift and structural change from highenergy intensive and carbon-intensive industries to services and informationintensive industries.

The increasing levels of carbon dioxide emissions in developing and least developing countries can be attributed to the economy driven by agriculture, transport, and services [35]. It has also been documented that an increase in FDI operations and industrialization had a positive and significant effect on $\mathrm{CO}_{2}$ emissions in the host country [42]. In Ghana, for instance, the operations of FDI have been increasing for the last decade but its effect on energy consumption is nothing to write home about. Results from research by Amoako and Insaidoo [43] suggest that energy-saving benefits from FDI operations are yet to be realized in Ghana as an increase in FDI increases the energy consumption of the nation. With all this being said, FDI has been documented to positively impact clean water infrastructure, sanitation, and renewable energy [44]. In India, a 1\% increase in FDI results in a $0.013 \%$ reduction in energy use. The adoption of energy-efficient techniques through FDI has been essential for reducing carbon emissions in India [45]. These are not realized yet in most African countries, it is like that such collaborations are underway if not already in inception.

\subsection{Interfirm Value Co-Creation}

Value co-creation is a deliberate act to create value in terms of products, services, or processes by engaging actors within a specific ecosystem [19]. It is a manner of business strategy which focuses on the generation and ongoing realization of mutual organization-customer value [46]. This is closely related to supply chain integration because in both cases a firm needs to open up to external collaborators [47]. While these two strategies have varying end-products, we expect SMEs engaged in supply chain integration to participate in interfirm value cocreation. This is supply chain integration creates a platform for interfirm value 
co-creation to thrive without extra cost [48]. Nonetheless, these strategic decisions could be driven by stakeholder pressure or the innovative capabilities of the firm [49] [50]. In a typical value co-creation ecosystem, members can take different forms; the idea generator, the designer, and or an intermediary to create value for all parties involved [51]. Similar to supply chain integration, the issue of transparency is coming up and members within the partnership are required to clearly define their roles, their identity as well as their potential contribution to the partnership [52]. Value co-creation comes in two main categories; business-to-customer platforms where co-creation activities mainly involve the business and both existing and potential customers, a business-to-to business where business within the same industry or different industry co-create value for their mutual gains [47]. Early studies paid much attention to business-to-customer platforms making studies on business-to-business value co-creation under-studied [52]. Previously organizations competed for resources, customers, and market share with little concern for collaboration. However, the current trend favors healthy competition and collaboration within an ecosystem with the aim of sustainable growth [19]. Organizations need to align promptly in a value co-creation partnership to take advantage of the integration of the resources to benefit from the partnership [51]. Value co-creation is proven to affect organizations' performance in areas such as cost savings, efficient use of resources, and efficient marketing in terms of compliment-complementary and services.

\subsection{Hypothesis Development}

Figure 1 depicts the expected relationships between the variables. Considering the topic under discussion, the research conceptual model was constructed following relevant literature which is illustrated in Figure 1. The figure depicts the expected affiliations between FDI inflow activities, environmental sustainability, economic sustainability, and social sustainability.

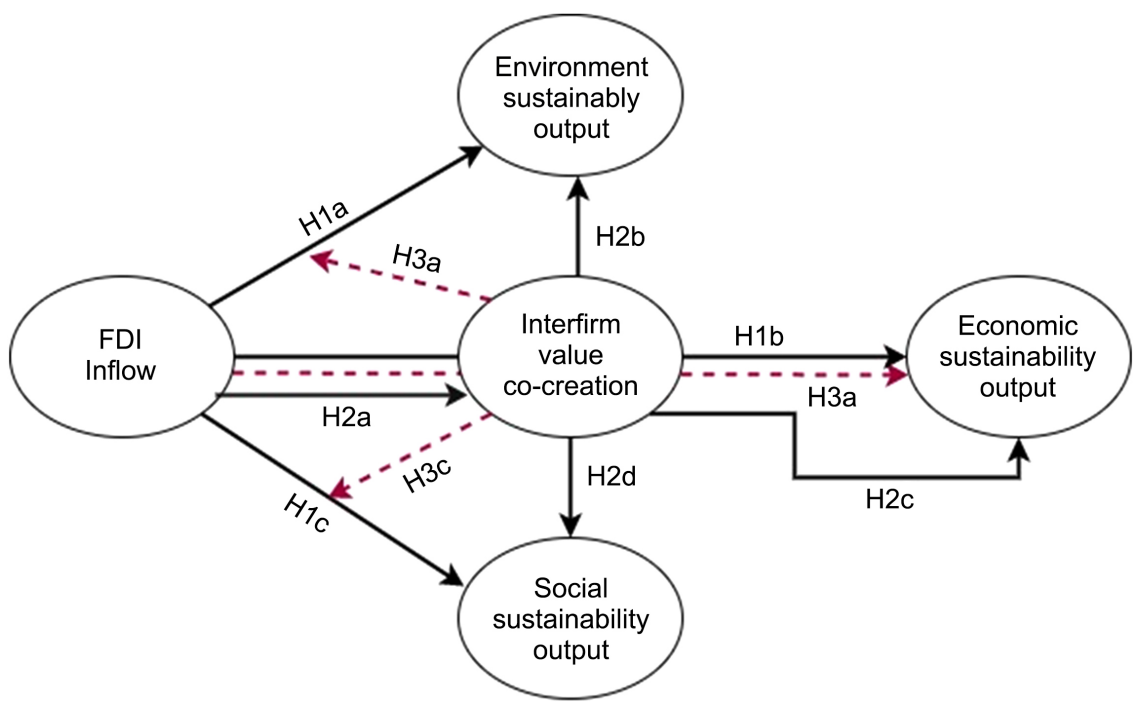

Figure 1. Conceptual framework. 
FDI inflow activities are evidenced to promote economic development, human capital development, and technology import [10] [11]. However, foreign-businesses seeking to operate in other economies must follow specific guidelines. Consequently, studies find a positive relationship between FDI inflow activities and environmental sustainability [26]. This is because these businesses are mandated to adopt sustainable resource usage. Therefore, we theorize that FDI inflow activities in Ghana would influence the decisions of domestic SMEs to follow the best environmental sustainability guidelines. Further, studies confirm a positive relationship between FDI inflow activities and economic sustainability [40]. This is because of the use of modern methods, processes, and equipment. Therefore, we posit that the increase in FDI inflow activities in Ghana would promote the economic sustainability of Ghanaian SMEs. This is because domestic SMEs are expected to learn from the best practices of these firms. Again, per literature, FDI inflow activities promote social sustainability [36]. Therefore, we propose that the increase in FDI inflow activities in Ghana would promote social sustainability decisions in Ghanaian SMEs. This is because foreign companies are expected to have the best human resource practices which intend would influence domestic businesses.

H1 a: FDI inflow activities positively affect Ghanaian SMEs' environmental sustainability decisions.

$H 1$ b: FDI inflow activities positively increases the economic sustainability decision of Ghanaian SMEs.

H1c. FDI inflow activities positively increases the social sustainability decision of Ghanaian SMES.

Interfirm value co-creation is a conscious effort by two or more businesses to create products or services via innovation to increase profitability [50]. Literature suggests that an increase in FDI inflow activities promotes interfirm value co-creation between foreign-owned businesses and domestic businesses [38]. Consequently, we expect an increase in FDI inflow activities in Ghana to promote interfirm value co-creation decisions of the Ghanaian SMEs. Further, interfirm value co-creation is theorized to increase firm performance [49]. Therefore, we expect the interfirm value co-creation decisions to increase environmental sustainability, economic sustainability, and social sustainability decisions in Ghanaian SMEs.

H2a: FDI inflow activities positively affect interfirm-value co-creation decision in Ghanaian SMEs

$H 2 b$ : Interfirm value co-creation positively increases Ghanaian SMEs environmental sustainability decision

H2c. Interfirm value co-creation positively increases the economic sustainability decision of Ghanaian SMEs

H2d: Interfirm value co-creation positively increases the social sustainability decision of Ghanaian SMEs 
Given the established relationships between FDI inflow activities and interfirm value co-creation decisions [38] and FDI inflow activities and firm performance [39], theorize that the expected relationship between FDI inflow activities and firm performance would be improved when domestic firms engage in interfirm value co-creation with foreign-owned companies. Consequently, we propose that interfirm value co-creation decisions mediate the positive relationship between FDI inflow activities and environmental sustainability, economic sustainability, and social sustainability decisions in Ghanaian SMEs.

H3a: Interfirm value co-creation decision mediates the positive relationship between FDI inflow activities and SMEs' environmental sustainability decision.

$H 3 \mathrm{~b}$ : Interfirm value co-creation decision mediates the positive relationship between FDI inflow activities and SMEs' economic sustainability decision.

H3c. Interfirm value co-creation decision mediates the positive relationship between FDI inflow activities and SMEs' social sustainability decision.

\section{Research Method}

\subsection{Data Source and Sampling Procedure}

The study explores the relationship between foreign direct investment and SMEs' strategic decisions in Ghana as well as the mediating role of interfirm value cocreation decisions. The study is quantitative with supporting world development index (WDI) and survey data from SMEs in Ghana. Currently, Ghana is home to numerous SMEs [1]. Therefore, we employ two sampling techniques: purposive non-probability sampling and simple random probability sampling. Using the purposive sampling technique, we include only SMEs documented with the association of Ghanaian Industries (AGI). This group of SMEs is appropriate for the study because they have frequent training on best managerial practices. Per AGI, there are 1600 plus active members scattered across the country. Consequently, we are unable to include all these SMEs in the study. Therefore, we sample further using the simple random probability technique. This provides equal inclusion opportunities for SMEs without bias. However, SMEs with invalid e-mails and unreachable telephone numbers are replaced in the process. Following, a total of 1010 SMEs with valid emails and reachable telephone numbers are included as the final sample of the study. Per the one-third sampling rule, the final sample of 1010 is way above 337 and thus representative of the study population. Thus, this provides substantiation for the generalization of our research findings. To collect data, a structured five-part closed-ended survey instrument covering demographics, FDI, EVS, ECS, SSS, and ITC is employed. Specifically, the questionnaire design is rooted in existing literature. The target respondents are the chief strategist of SMEs. Usually, the owners of SMEs in Ghana are the same as the chief strategist. Thus, strategic decisions like the engagement in interfirm value co-creation rest with CEOs or the owners. To ensure the suitability of the survey instrument, we employ the split-half by sending 
a sample of the instrument to 75 of the selected SMEs. Afterward, changes were made to the instrument to provide clarity and ensure internal consistency. To draft the final questionnaire, the improved instrument is further sent to 45 of the selected SMEs. This process produced a refined instrument free from ambiguity. The approved questionnaire was then sent to the 1010 SMEs via email. The entire data collection period lasted between March 2020-September 2020. The final response generated yielded 856 (1010). This difference is accounted for by the fact that some SMEs did not attend to their emails or answer our follow-up telephone calls. Nonetheless, the response rate is great and thus reduces the probability of non-response rate bias. Table 1 shows the data descriptiong and sources.

\subsection{Model Specification}

Investment (FDI) and environmental sustainability decisions (EVS), economic sustainability decisions (ECS), and social sustainability decisions (SSS). We also estimate the mediating role of interfirm value co-creation decisions (ITC) in the relationships. This model allows complex relationships between one or more independent variables as well as one or more dependent variables. This statistical technique allows the estimation of multilevel regression models and is applied to testing research hypotheses that contain direct and indirect observations of one or more dependent and independent variables respectively. The main reason behind adopting the SEM technique in this study is to examine and as well validate the proposed casual model illustrated in Figure 1. Considering a structural model that contains four (5) variables; FDI, EVC, ECS, ESS, and ITC, where firm FDI is the response variable (Y) or the endogenous variable while EVS, ECS, and SSS are exogenous variables (Xs) with ITC as a dependent (endogenous) on both aforementioned and independent variables and at the same as an explanatory variable $(\mathrm{X})$ on the FDI within the entire model. The model can therefore be presented theoretically in a matrix form as:

Table 1. Data description and sources.

\begin{tabular}{|c|c|c|c|}
\hline Constructs & Elements & Measure & References \\
\hline $\begin{array}{l}\text { FDI } \\
\text { inflow activities }\end{array}$ & $\begin{array}{l}\text { Start-ups Acquisition } \\
\text { and mergers }\end{array}$ & $\begin{array}{l}2 \text { questions } \\
2 \text { questions }\end{array}$ & [5] [28] \\
\hline $\begin{array}{c}\text { Interfirm value } \\
\text { co-creation decisions }\end{array}$ & $\begin{array}{l}\text { Approaches and } \\
\text { measurement }\end{array}$ & 5 questions & [51] [52] [53] \\
\hline \multirow{3}{*}{$\begin{array}{c}\text { SMEs } \\
\text { strategic decisions }\end{array}$} & $\begin{array}{c}\text { Environmental } \\
\text { sustainability decisions }\end{array}$ & 5 questions & \multirow{3}{*}{ [12] [13] } \\
\hline & $\begin{array}{c}\text { Economic sustainability } \\
\text { decisions }\end{array}$ & 5 questions & \\
\hline & $\begin{array}{l}\text { Social sustainability } \\
\text { decisions }\end{array}$ & 5 questions & \\
\hline
\end{tabular}




$$
\left[\begin{array}{l}
y_{1} \\
\cdots \\
y_{p}
\end{array}\right]=\left(\begin{array}{ccc}
0 & \cdots & \beta_{1 p} \\
\vdots & \ddots & \vdots \\
\beta_{p 1} & \cdots & 0
\end{array}\right)\left[\begin{array}{l}
y_{1} \\
\cdots \\
y_{p}
\end{array}\right]+\left(\begin{array}{ccc}
\delta_{11} & \cdots & \delta_{1 q} \\
\vdots & \ddots & \vdots \\
\delta_{p 1} & \cdots & \delta_{p q}
\end{array}\right)\left[\begin{array}{c}
x_{1} \\
\cdots \\
x_{q}
\end{array}\right]+\left[\begin{array}{c}
\varepsilon_{1} \\
\cdots \\
\varepsilon_{p}
\end{array}\right]
$$

Summarily the matrix equation in Equation (1) can be reformulated as:

$$
Y=\boldsymbol{B} Y+\Gamma X+\varepsilon
$$

where $p$ represents the number of regression equations to be estimated simultaneously, $p$ by $p$ B square matrix contains the parameter coefficients of the regressors of $Y$ variables on the other $Y$ variables with the 0 diagonal values implying that a variable cannot cause itself. Also, the $p$ by $q \Gamma$ matrix contains coefficients of the $Y$ s on $X$ s whereas $\varepsilon$ is a $p$ by 1 vector consisting of residual terms. Based on the theoretical model specification, a deduction can be made that series of regression equations are to be estimated to assess the causal effects amid the variables employed in the study which can found in the structural model as Figure 1 depicts. Thus, regarding the theoretical model formulated in Equation (1) and the structural model from Figure 1, the series of regression equations to be estimated as specified as follows;

$$
\begin{aligned}
& \mathrm{FDI}_{i}=\beta_{0}+\beta_{a} \mathrm{EVS}+\varepsilon_{i} \\
& \mathrm{FDI}_{i}=\beta_{0}+\beta_{b} \mathrm{ECS}+\varepsilon_{i} \\
& \mathrm{FDI}_{i}=\beta_{0}+\beta_{c} \mathrm{SSS}+\varepsilon_{i} \\
& \mathrm{FDI}_{i}=\beta_{0}+\beta_{d} \mathrm{ITC}+\varepsilon_{i} \\
& \mathrm{EVS}_{i}=\beta_{0}+\beta_{d} \mathrm{ITC}+\varepsilon_{i} \\
& \mathrm{ECS}_{i}=\beta_{0}+\beta_{d} \mathrm{ITC}+\varepsilon_{i} \\
& \mathrm{SSS}_{i}=\beta_{0}+\beta_{d} \mathrm{ITC}+\varepsilon_{i} \\
& \mathrm{FDI}_{i}=\beta_{0}+\beta_{d} \mathrm{ITC}^{*}+\beta_{a} \mathrm{EVS}+\varepsilon_{i} \\
& \mathrm{FDI}_{i}=\beta_{0}+\beta_{d} \mathrm{ITC}^{*}+\beta_{a} \mathrm{ECS}+\varepsilon_{i} \\
& \mathrm{FDI}_{i}=\beta_{0}+\beta_{d} \mathrm{ITC}^{*}+\beta_{a} \mathrm{SSS}+\varepsilon_{i}
\end{aligned}
$$

where FDI, EVS, ECS, SSS, and ITC, represent foreign direct investment, environmental sustainability, economic sustainability decisions, social sustainability decisions, and interfirm value co-creation decisions respectively. Equations (3i) and $(3 \mathrm{j})$ estimate the mediating effect of ITC in the relationship between FDI and EVS, ECS, SSS respectively.

\subsection{Statistical Analysis}

This section presents the results of the descriptive analysis, reliability test, validity test, and test of hypotheses.

\subsubsection{Descriptive Analysis}

Table 2 shows the summary of descriptive statistics for the demographic background of the survey respondents. The age of the respondents (SMEs Chief strategist) shows a mean value of 2.64 with a standard deviation of 1.03 . Gender has 
Table 2. Summary of descriptive statistics.

\begin{tabular}{cccccc}
\hline Variables & Mean & Std. Dev & Kurtosis & Jarque-Bera & Response rate \\
\hline Age & 2.64 & 1.03 & 2.15 & $105.93^{\mathrm{a}}$ & \\
Gender & 1.50 & 0.72 & 2.59 & $147.14^{\mathrm{a}}$ & \\
Education & 2.93 & 0.28 & 2.63 & $179.12^{\mathrm{a}}$ & $856(1010)$ \\
Location of Business & 1.23 & 0.42 & 2.56 & $153.12^{\mathrm{a}}$ & $85 \%$ \\
Number of employees & 15.49 & 0.92 & 2.47 & $399.86^{\mathrm{a}}$ & \\
\hline
\end{tabular}

Note: a Denotes statistical significance at $5 \%$.

a mean value of 1.5 with a standard deviation of 0.72 . Further, the level of education has a mean value of 2.93 and a standard deviation of 0.28 . Further, the location of the SMEs and the number of employees show mean values and standard deviations of $1.23(0.42)$ and 15.49 (0.92) respectively. The value from the mean and standard deviation portrays that the respondents have diverse backgrounds. This is supported by the fact that the mean values are above 1.0 and the standard deviation is above 0.00 . Therefore, the possibility of response bias is eliminated. To further establish the non-biasness of the response, we estimate the kurtosis and JB test. According to the kurtosis, the age and level of education distribution of the respondents have values more than 3 to show a heavy tail distribution. Gender, location of the business, and the number of employees show values less than 3. None of the measures of the kurtosis examination was evidenced to be Leptokurtic in distribution. Since none of the values of kurtosis assumes " 0 " and " 3 " respectively, all demographic factors of the respondents are assumed not to follow a normal distribution. This is supported by the JB-test which rejects the null hypothesis of demographic factors being normally distributed all at a $1 \%$ level of significance.

To provide evidence of the recent growth in FDI inflow activities in Ghana, Figure 2 depicts the inflow of FDI from 1970-2018 in the US dollar. The trend shows that since 2008, the number of FDI inflow activities in Ghana has risen sharply compared to the period of 1970-2006. However, after the year 2016, FDI inflow took a decreasing trend because of the change in government and unstable exchange rate. Nonetheless, the launch of the "Year of return" by the president of Ghana in 2019, there has been an increase in FDI inflow. This supports the recent dilemma of domestic SMEs on the chances of surviving the competition with these foreign-owned businesses. However, we expect the inflow of these businesses to positively influence the operations of the domestic SMEs to promote environmental, economic, and social sustainability decisions.

\subsubsection{Reliability and Validity Tests}

Before estimating our proposed structural equation model to test the relationship between our proposed variables, we perform reliability and validity test on the research instruments. Precisely, we use Cronbach's alpha, composite reliability, KMO and Bartlett's and, Herman single factor tests. 


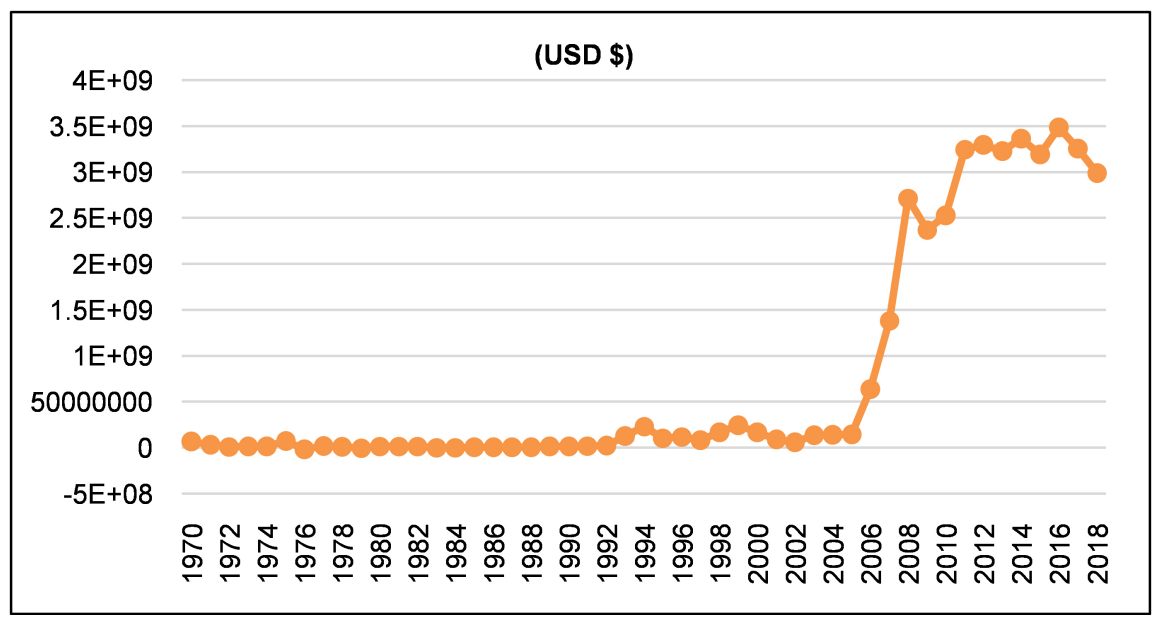

Figure 2. FDI inflow in Ghana from 1970-2018 (Data Source: WDI 2018).

Table 3 shows the results from the tests. We estimate the internal consistency of the research instruments with Cronbach's alpha. Hence, the value reported for Cronbach's alpha are all greater than 0.7 and establishes the consistency of the research instrument. Again, we use the composite reliability to estimate the overall scale reliability of the research instrument. The value of more than 0.8 supports that the instrument is reliable. Further, we test for the sampling adequacy using the KMO and Bartlett's test. The result of 0.830 and a probability of 0.00 reveals the adequacy of the study sample. Finally, we employ the Herman single factor test using the principal Axis Factoring (PAF) by loading 24 items on a single factor to investigate the issue of common method variance. The results show a total variance explained of $35.51 \%$ significantly less than $50 \%$. Therefore, common factor variance is an issue in this study. Consequently, this provides adequate evidence to support the outcome of the study.

After establishing the reliability of the research instrument, we proceed to test the validity of the research instrument using the cross-loading factor and the average variance extracted (AVE). Table 4 shows the results of the validity test. The expected values of the cross-loading factor must be greater than 0.7. Consequently, the results show that all the constructs have cross-loading values greater than 0.7 . This proves that the items adequately support the various constructs within the study. Further, the outcome of the AVE is expected to show values greater than 0.5 . Therefore, the stated constructs all show values of more than 0.5 to prove that the research instrument meets both reliability and validity requirements to warrant further investigation. Therefore, we proceed to estimate our structural equation model outlined in Equations (3a)-(3j).

\subsubsection{Hypothesis Testing}

After meeting the reliability and validity requirements of the research instruments, we test the study hypotheses using the smart PLS. The study employs the probability value $(<0.05)$ and positive coefficients as the standard for accepting or rejecting the research hypotheses. Table 5 is the output of the estimation. 
Table 3. Reliability test.

\begin{tabular}{ccccc}
\hline Variables & Cronbach's alpha & $\begin{array}{c}\text { Composite } \\
\text { reliability }\end{array}$ & KMO \& B & HSF \\
\hline FDI & 0.799 & 0.872 & Value & \\
EVS & 0.858 & 0.901 & 0.830 & \\
ECS & 0.770 & 0.862 & & \\
SSS & 0.715 & 0.811 & Probability & \\
ITC & 0.747 & 0.834 & 0.00 & \\
\hline
\end{tabular}

Table 4. Cross factor loading and Average Variance Extracted (AVE).

\begin{tabular}{|c|c|c|c|c|c|}
\hline Components & FDI & EVS & ECS & SSS & ITC \\
\hline FDI1 & 0.788 & 0.281 & -0.030 & 0.494 & 0.100 \\
\hline FDI2 & 0.702 & -0.118 & -0.022 & 0.207 & -0.223 \\
\hline FDI3 & 0.739 & -0.313 & 0.240 & 0.404 & -0.217 \\
\hline FDI4 & 0.735 & -0.323 & -0.222 & -0.153 & 0.270 \\
\hline EVS1 & 0.708 & 0.739 & -0.261 & -0.140 & 0.033 \\
\hline EVS2 & 0.697 & 0.623 & -0.257 & -0.152 & 0.133 \\
\hline EVS3 & 0.664 & 0.727 & -0.269 & -0.107 & -0.010 \\
\hline EVS4 & 0.733 & 0.686 & -0.018 & -0.267 & -0.017 \\
\hline EVS5 & 0.758 & 0.787 & 0.001 & -0.218 & -0.147 \\
\hline ECS1 & 0.751 & -0.324 & 0.784 & 0.091 & -0.157 \\
\hline ECS2 & 0.791 & -0.228 & 0.852 & -0.077 & -0.227 \\
\hline ECS3 & 0.530 & 0.390 & 0.541 & 0.162 & -0.016 \\
\hline ECS4 & 0.628 & 0.380 & 0.612 & 0.132 & -0.179 \\
\hline ECS5 & 0.512 & 0.451 & 0.747 & 0.115 & 0.244 \\
\hline SSS1 & 0.547 & 0.325 & -0.461 & 0.679 & 0.215 \\
\hline SSS2 & 0.434 & 0.275 & 0.255 & 0.701 & 0.388 \\
\hline SSS3 & 0.571 & -0.075 & 0.324 & 0.760 & 0.521 \\
\hline SSS4 & 0.417 & -0.060 & 0.665 & 0.741 & 0.259 \\
\hline SSS5 & 0.579 & 0.044 & 0.353 & 0.681 & 0.139 \\
\hline ITC1 & 0.465 & 0.257 & 0.489 & 0.404 & 0.728 \\
\hline ITC2 & 0.549 & 0.279 & 0.109 & -0.240 & 0.746 \\
\hline ITC3 & 0.560 & 0.456 & 0.097 & -0.275 & 0.671 \\
\hline ITC4 & 0.524 & 0.551 & 0.222 & -0.134 & 0.727 \\
\hline ITC5 & 0.481 & 0.304 & -0.044 & 0.503 & 0.731 \\
\hline $\begin{array}{l}\text { Average Variance } \\
\text { Extracted (AVE) }\end{array}$ & 0.732 & 0.645 & 0.686 & 0.682 & 0.679 \\
\hline
\end{tabular}


Table 5. Hypothesis testing.

\begin{tabular}{ccccccc}
\hline Hypotheses & Relationships & Coefficients & p. Values & Effect & Sign & Results \\
\hline H1a & FDI-EVS & 0.708 & $0.000^{\mathrm{a}}$ & Direct & + & Supported \\
H1b & FDI-ECS & 0.463 & $0.000^{\mathrm{a}}$ & Direct & + & Supported \\
H1c & FDI-SSS & 0.361 & $0.000^{\mathrm{a}}$ & Direct & + & Supported \\
H2a & FDI-ITC & 0.470 & $0.000^{\mathrm{a}}$ & Direct & + & Supported \\
H2b & ITC-EVS & 0.118 & $0.000^{\mathrm{a}}$ & Direct & + & Supported \\
H2c & ITC-ECS & 0.383 & $0.000^{\mathrm{a}}$ & Direct & + & Supported \\
H2d & ITC-SSS & 0.448 & $0.000^{\mathrm{a}}$ & Direct & + & Supported \\
H3a & FDI-ITC-EVS & -0.006 & 0.879 & Indirect & - & Not supported \\
H3b & FDI-ITC-ECS & 0.131 & $0.000^{\mathrm{a}}$ & Indirect & + & Supported \\
H3c & FDI-ITC-SSS & -0.074 & 0.093 & Indirect & - & Not supported \\
\hline
\end{tabular}

Note: $\mathrm{a}$ and $\mathrm{b}$ represent $1 \%$ and $5 \%$ level of significance respectively.

At a 5\% (0.05) significant level, we find that all the hypotheses (H1a, H1b, H1c, $\mathrm{H} 2 \mathrm{a}, \mathrm{H} 2 \mathrm{~b}, \mathrm{Hbc}, \mathrm{H} 2 \mathrm{c}, \mathrm{H} 2 \mathrm{~d}$, and H3b) significant except H3a and H3c. FDI inflow activities have a $0.000^{\mathrm{a}}$ significant relationship with EVS at a coefficient of 0.708 . This means that an increase in FDI inflow activities increases the EVS of Ghanaian SMEs. This finding is consistent with existing studies [26]. FDI inflow activities and ECS show a significant positive relationship with a coefficient of 0.463 and a p. Value of $0.000^{2}$. Thus, a unit increase in FDI inflow activities increases the ECS of Ghanaian SMEs by 0.463 . The established positive relationship supports the findings of existing studies [36] [40]. Further, FDI inflow activities show a positive significant relationship with SSS in Ghanaian SMEs. This is supported by a coefficient of 0.361 and a p. Value of $0.000^{a}$. This reveals that the increase in FDI inflow activities in Ghana promotes SSS in Ghanaian SMEs.

This is synonymous with the findings of [36] [40] to prove that FDI increases the performance of SMEs. FDI inflow activities in Ghana are evidenced to influence ITC in Ghanaian SMEs. This is supported with a coefficient of 0.470 and a p. Value of $0.000^{\mathrm{a}}$. This result confirms the assertion of [38] to prove that economies with increased FDI inflow activities have a higher probability of ITC within their SMEs. ITC shows a positive relationship with EVS with a coefficient of 0.118 and a $\mathrm{p}$. Value of $0.000^{\mathrm{a}}$. This could be explained by the positive relationship established between FDI inflow activities and ITC in Ghanaian SMEs. Further, this outcome is supported by the studies of [36]. ITC shows a positive relationship with ECS with a coefficient of 0.383 and a p. Value of $0.000^{\mathrm{a}}$. This is supported by the fact that FDI shows a significant positive relationship with ITC in Ghanaian SMEs. Again, ITC shows a significant positive relationship with SSS with a coefficient of 0.448 and a p. Value of $0.000^{\mathrm{a}}$. This supports the outcome of existing studies [32]. Further, we test for the mediating effect of ITC in the rela- 
tionships between FDI inflow activities and EVS, ECS, and SSS. We find that ITC positively mediates the relationship between FDI inflow activities and ECS of SMEs in Ghana with a coefficient of 0.131 and a p. Value of $0.000^{\mathrm{a}}$. While this is consistent with the literature [36] [49]. ITC shows no significant mediation between FDI inflow activities and EVS and SSS. This contradicts the expected outcome of existing studies [33].

Figure 3 depicts the output of the smart PLS. It shows the path coefficients and the values of the adjusted $\mathrm{R}^{2}$. Hypothetically, these models show adjusted $\mathrm{R}^{2}$ values of more than 0.5 to prove that the models explain more than $50 \%$ of the variations in the relationships estimated. Consequently, the model performs better above a zero model.

\section{Discussion}

The study estimates the relationship between FDI inflow activities in Ghana and the influence on strategic decisions (EVS, ECS, and SSS). While the direct relationship between FDI and EVS, ECS, and SSS are all witnessed to be positively significant, the mediating role of ITC has mixed outcomes. We discuss the results in detail.

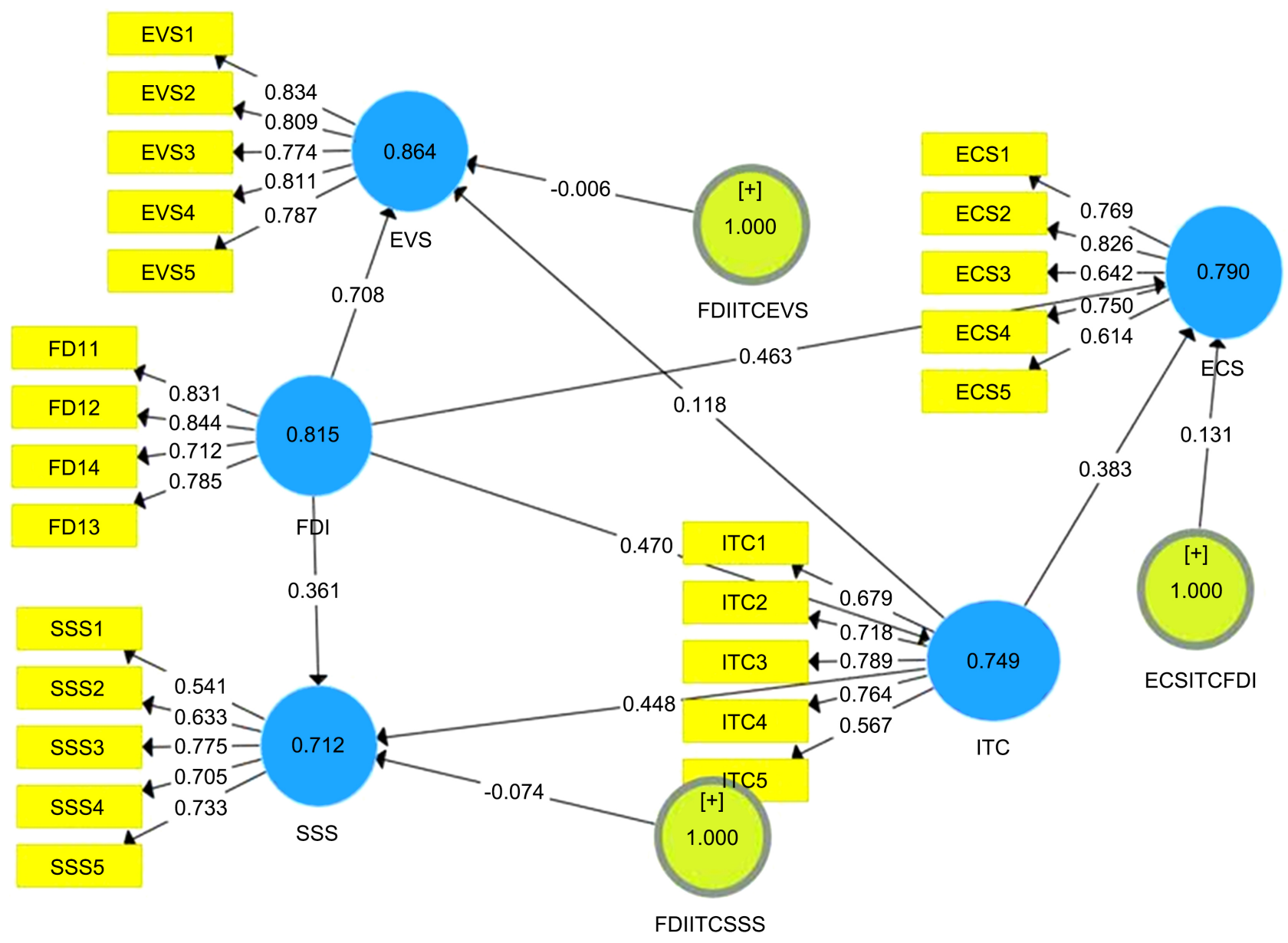

Figure 3. Output of the smart PLS. 
FDI positively influences EVS decisions in Ghanaian SMEs. While this result is consistent with existing literature on the role of FDI in improving environmental sustainability [26]. It equally unearths the significance of FDI in driving environmental sustainability awareness amongst domestic SMEs. This is because foreign-owned businesses are mandated to engage in environmentally friendly resource utilization, so the industry best practices become apparent to their domestic counterparts [33]. Thus, government policies to increase FDI inflow activities should stress the use of modern equipment and environmentally friendly activities. Further, subsidy support should be given to domestic SMEs investing in environmentally sustainable equipment and practices. Synonymous with existing literature [40] FDI inflow activities positively affect ECS in Ghanaian SMEs. This justifies the impact of technology and expertise import on economic development [32] [38]. Adopting industry best practices could increase the production and profitability of domestic SMEs. The case of Ghanaian SMEs is explained by the fact that these businesses are ready to learn and adopt industry best practices constantly evolving with the influx of foreign-owned businesses [50]. Therefore, in as much as a cross-section of these business owners frown on FDI inflow activities, a conscious effort to acquire knowledge from these firms could increase the economic output of the domestic SMEs through strategic planning. Consequently, the government can create avenues for strategic collaboration between foreign-owned businesses and domestic businesses to eliminate the fear and the perceived unfair advantage enjoyed by foreign-owned businesses in the country. Further, FDI inflow activities positively affect SSS in Ghanaian SMEs. This outcome could be explained by the fact that FDI inflow activities come with new processes, technologies, and expertise that is capable of transforming the human resource output [26] [36]. Therefore, Ghanaian SMEs benefit from this situation by following these improved structures and processes to advance the output and lives of employees. Therefore, contrary to the negative perception of domestic SMEs about FDI inflow activities in Ghana, improved government policies can create a win-win ecosystem.

FDI inflow activities in Ghana positively affect inter-firm value co-creation decisions (ITC). This supports the outcome of existing literature [38] [39] to suggests that the inflow of FDI in an economy creates avenues for collaboration between domestic and foreign firms. However, the case of Ghanaian SMEs could be explained by two reasons; the need for these SMEs to partners with other domestic firms to compete with the foreign-owned businesses or the need for these domestic SMEs to partner with the foreign-owned companies to avoid the competition from the foreign-owned businesses. Irrespective of the rationale, inter-firm value co-creation is desirable for improved firm performance [49] [50]. Inter-firm value co-creation decisions positively affect EVS in Ghanaian SMEs. This supports the assertion of [49] to show that firms collaborating for a common goal have a higher probability of engaging in environmentally friendly practices. Therefore, to improve environmentally friendly practices in Ghana, 
the role of FDI inflow activities and inter-firm value co-creation decisions are significant. Inter-firm value co-creation decisions positively affect ECS, this is established in the literature [40] to show that inter-firm value co-creation decisions birth innovation, creativity, and high firm performance. Consequently, Ghanaian SMEs can create value and improve firm performance through collaboration with foreign-owned businesses. Finally, inter-firm value co-creation decisions positively affect SSS, this is possible because the successful diffusion of inter-firm value co-creation requires the seamless integration of business processes [50]. Thus, Ghanaian SMEs engaging in collaborations with either foreign-owned or domestic businesses are likely to engage in the best human resources practices. So, to boost the productivity of the Ghanaian industry through innovation and creativity, government policies should encourage inter-firm value co-creation collaborations.

In testing the mediating role of SMEs ITC decisions in the relationship between FDI, EVS, ECS, and SSS in Ghana, we find an insignificant mediating role of ITC decisions in the relationship between FDI and EVS. This result could be explained by the fact that environmentally friendly practices are not the main reasons behind the inter-firm value co-creation collaborations of these SMEs. Therefore, government policies to promote foreign-owned business and domestic SMEs collaboration should have incentives for partnerships with environmentally friendly outcomes. However, ITC decisions positively mediate the relationship between FDI inflow activities and ECS in Ghanaian SMEs. This outcome is synonymous with the findings of [49] [50] to prove that the main purpose of inter-firm value co-creation decisions is to create value and maximize the economic value of collaborating firms. Thus, domestic SMEs have a higher likelihood of increasing productivity through strategic partnerships with foreign-owned businesses. Nonetheless, ITC decisions show a non-significant mediating role in the relationship between FDI inflow activities and SSS. While this contradicts the earlier results which establish a significant positive relationship between FDI and SSS and ITC and SSS, it supports the assertion that most inter-firm value co-creation partnerships in Ghana are for economic gains. Therefore, SMEs can optimize their gains if EVS, ECS, and SSS are all considered in ITC partnerships with foreign-owned businesses.

\section{Conclusions}

The study evaluates the relationship between FDI inflow activities in Ghana and the influence on SMEs' strategic decisions (EVS, ECS, and SSS). We conclude that all the direct relationships examined in the study between FDI inflow activities, EVS, ECS, and SSS are positively significant. However, ITC decisions mediate the positive relationship between FDI inflow activities and ECS.

FDI inflow activities positively affect EVS in Ghanaian SMEs. This could be explained by the fact that foreign-owned businesses are known to engage in environmentally friendly practices in host-countries which changes the landscape 
of the industry. Further, the need for domestic SMEs to compete with these businesses drives their participation in environmentally friendly practices. Thus, a regulated influx of foreign-owned businesses is desirable for the environmental sustainability of Ghana. FDI inflow activities positively influence ECS in Ghanaian SMEs. Foreign-owned businesses can invest and introduce new equipment, processes, technology, and procedures in the host country. This creates the need for domestic SMEs to improve their existing systems and processes to meet the competition and thus drives productivity. Therefore, the influx of foreign-owned businesses creates a knowledge repository that challenges SMEs to invest in modern technologies and engage in industry best practices. Again, FDI positively affects SSS in Ghanaian SMEs. Besides technology transfer from FDI inflow activities, foreign-owned businesses also come with managerial expertise. Therefore, domestic SMEs can learn and adopt these practices to improve human resource management. Subsequently, the government should institute policies that promote progressive collaboration between domestic SMEs and foreign-owned businesses.

FDI inflow activities in Ghana positively affect inter-firm value co-creation decisions in Ghanaian SMEs. This is explained by the fact the SMEs need to survive the competition of foreign-owned businesses through collaboration with domestic SMEs. Further, these collaborations could be triggered by the fact that the SMEs need to avoid competition by collaborating with foreign-owned businesses. Either of these collaborations is desirable, therefore, the government should institute policies that create fair competition to drive purposeful collaborations. Inter-firm value co-creation affects EVS in Ghanaian SMEs. This is explained by the fact that collaborations are built on the best practices of individual firms. Further, it could be explained by the dominance of the foreign-owned firm in the partnerships. Therefore, the call for environmental sustainability in Ghana can be answered with the collaboration between domestic and foreign-owned businesses. Further, ITC influences ECS in Ghanaian SMEs. This is because the purpose of inter-firm value co-creation is the create value through the sharing of ideas, resources, and expertise. Therefore, the government of Ghana should provide incentives to drive domestic and foreign-owned business partnerships at different levels. Finally, ITC drives SSS in Ghanaian SMEs. This is possible because, through the collaborative effort of two or more businesses, the best human resource practices can be exchanged. Therefore, the overall gains of FDI inflow activities in Ghana to SMEs could significantly surpass the perceived disadvantages if great policies are instituted to create a win-win ecosystem.

Finally, the positive relationship between FDI inflow activities and EVS in Ghanaian SMEs is not explained by ITC. This is mainly because of the partnership arrangements of the party's centers around product innovation and creativity. Again, this could explain the minimal interest of Ghanaian SMEs in environmentally friendly practices. Therefore, government policies to promote collaborations with domestic SMEs and foreign-owned businesses can offer addi- 
tional incentives for businesses collaborating for a sustainable environment. Contrary, ITC significantly explains the relationship between FDI inflow activities in Ghana and the ECS of SMEs. This is explained by the fact that inter-firm value co-creation between firms generates innovative products and services. Thus, SMEs can collaborate with foreign-owned businesses to take advantage of their technologies, processes, and procedures. Finally, ITC failed to explain the relationship between FDI inflow activities and SSS in Ghanaian SMEs. Therefore, besides, ECS Ghanaian SMEs should collaborate for EVS and SSS sustainability.

\section{Implications for Future Studies}

The study estimates the relationship between FDI inflow activities and SMEs' strategic decisions (EVS, ECS, and SSS) in Ghanaian SMEs. The study employs primary data given the unavailability of data on SMEs activities in connection with FDI in the country. This study could be replicated in other countries where secondary data is readily available. We expect future studies to focus primarily on the relationship between FDI inflow activities and the environmental sustainability decisions of SMEs. This is because currently, environmental degradation has become a problem in Ghana. Therefore, the outcome of future studies in this area could shed light on the phenomenon.

\section{Conflicts of Interest}

The authors declare no conflicts of interest.

\section{References}

[1] Quartey, P., Turkson, E., Abor, J.Y. and Iddrisu, A.M. (2017) Financing the Growth of SMEs in Africa: What Are the Contraints to SME Financing within ECOWAS? Review of Development Finance, 7, 18-28. https://doi.org/10.1016/j.rdf.2017.03.001

[2] Abor, J. and Quartey, P. (2010) Issues in SME Development in Ghana and South Africa. International Research Journal of Finance and Economics, 39, 218-228.

[3] Oduro, S. (2020) Exploring the Barriers to SMEs' Open Innovation Adoption in Ghana: A Mixed Research Approach. International Journal of Innovation Science. https://doi.org/10.1108/IJIS-11-2018-0119

[4] Barthel, F., Busse, M. and Osei, R. (2011) The Characteristics and Determinants of FDI in Ghana. The European Journal of Development Research, 23, 389-408. https://doi.org/10.1057/ejdr.2011.4

[5] Asiamah, M., Ofori, D. and Afful, J. (2019) Analysis of the Determinants of Foreign Direct Investment in Ghana. Journal of Asian Business and Economic Studies, 26, 56-75. https://doi.org/10.1108/JABES-08-2018-0057

[6] Acheampong, P. and Osei, V. (2014) Foreign Direct Investment (FDI) Inflows into Ghana: Should the Focus Be on Infrastructure or Natural Resources? Short-Run and Long-Run Analyses. International Journal of Financial Research, 5, 42-51. https://ideas.repec.org/a/jfr/ijfr11/v5y2014i1p42-51.html https://doi.org/10.5430/ijfr.v5n1p42

[7] Hou, L., Li, K., Li, Q. and Ouyang, M. (2021) Revisiting the Location of FDI in 
China: A Panel Data Approach with Heterogeneous Shocks. Journal of Economics, 221, 483-509. https://doi.org/10.1016/j.jeconom.2020.04.047

[8] Pan, X., Guo, S., Han, C., Wang, M., Song, J. and Liao, X. (2020) Influence of FDI Quality on Energy Efficiency in China Based on Seemingly Unrelated Regression Method. Energy, 192, Article ID: 116463. https://doi.org/10.1016/j.energy.2019.116463

[9] Zangina, S. and Hassan, S. (2020) Corruption and FDI Inflow to Nigeria: A Nonlinear ARDL Approach. The Journal of Financial Crime, 27, 635-650. https://doi.org/10.1108/JFC-09-2019-0116

[10] Kannen, P. (2020) Does Foreign Direct Investment Expand the Capability Set in the Host Economy? A Sectoral Analysis. The World Economy, 43, 428-457. https://doi.org/10.1111/twec.12869

[11] Demena, B.A. and Afesorgbor, S.K. (2019) The Effect of FDI on Environmental Emissions: Evidence from a Meta-Analysis. https://www.iss.nl/en/library

[12] Dong, Y. and Hauschild, M.Z. (2017) Indicators for Environmental Sustainability. Procedia CIRP, 61, 697-702. https://doi.org/10.1016/j.procir.2016.11.173

[13] Keirstead, J. and Leach, M. (2008) Bridging the Gaps between Theory and Practice: A Service Niche Approach to Urban Sustainability Indicators. Sustainable Development, 16, 329-340. https://doi.org/10.1002/sd.349

[14] Hauser, A., Eggers, F. and Güldenberg, S. (2020) Strategic Decision-Making in SMEs: Effectuation, Causation, and the Absence of Strategy. Small Business Economics, 54, 775-790. https://doi.org/10.1007/s11187-019-00152-x

[15] Osei, C., Omar, M. and Joosub, T.S. (2020) The Effect of Colonial Legacies on Africa's inward FDI: The Case of UK FDI in Ghana. Critical Perspectives on International Business, 16, 259-277. https://doi.org/10.1108/cpoib-05-2018-0041

[16] Adongo, S.A., Chen, L., Xuhua, H. and Serwaa Obobisa, E. (2017) A Causality Analysis for FDI and Economic Growth in Ghana. European Journal of Contemporary Research, 1, 312-317. http://onlinejournal.org.uk/index.php/ejocr

[17] Boakye-Gyasi, K. and Li, Y. (2017) FDI Trends in Ghana: The Role of China, Us, India and South Africa. Eurasian Journal of Economics and Finance, 5, 1-16.

https://ideas.repec.org/a/ejn/ejefjr/v5y2017i2p1-16.html https://doi.org/10.15604/ejef.2017.05.02.001

[18] Fisher, G.J. and Qualls, W.J. (2018) A Framework of Interfirm Open Innovation: Relationship and Knowledge Based Perspectives. Journal of Business \& Industrial Marketing, 33, 240-250. https://doi.org/10.1108/JBIM-11-2016-0276

[19] Braun, E.L., Pereira, G.M., Sellitto, M.A. and Borchardt, M. (2017) Value Co-Creation in Maintenance Services: Case Study in the Mechanical Industry. Business Process Management Journal, 23, 984-999. https://doi.org/10.1108/BPMJ-09-2014-0090

[20] Anning-Dorson, T. and Nyamekye, M.B. (2020) Engagement Capability, Innovation Intensity and Firm Performance: The Role of Competitive Intensity. Journal of African Business, 21, 493-508. https://doi.org/10.1080/15228916.2020.1790914

[21] Awunyo-Vitor, D. and Sackey, R.A. (2018) Agricultural Sector Foreign Direct Investment and Economic Growth in Ghana. Journal of Innovation and Entrepreneurship, 7, 1-15. https://doi.org/10.1186/s13731-018-0094-3

[22] Atta-Krah, K.D. (2016) Preventing a Boom from Turning Bust: Regulators Should Turn Their Attention to Starter Interrupt Devices before the Subprime Auto Lending Bubble Bursts. Iowa Law Review, 101, 1187-1222.

[23] Osabuohien, E.S. and Karakara, A.A. (2018) ICT Usage, Mobile Money and Finan- 
cial Access of Women in Ghana. Africagrowth Agenda Journal, 15, 14-18. http://journals.co.za/content/journal/10520/EJC-dc947bee3

[24] Das Gupta, A. (1967) Recent Developments in Africa. Africa Quarterly, 7, 4-11.

[25] Ndiwalana, A., Morawczynski, O. and Popov, O. (2010) Mobile Money Use in Uganda: A Preliminary Study. M4D, 121.

http://mmublog.org/wp-content/files_mf/m4dmobilemoney.pdf

[26] Munir, K. and Ameer, A. (2020) Nonlinear Effect of FDI, Economic Growth, and Industrialization on Environmental Quality: Evidence from Pakistan. Management of Environmental Quality: An International Journal, 31, 223-234. https://doi.org/10.1108/MEQ-10-2018-0186

[27] Lawson, J., Du, K. and Bentum-Micah, G. (2019) The Impact of Macroeconomic Variables, Investment Incentives and Government Agreements on FDI Inflows in Ghana. https://papers.ssrn.com/abstract=3461108 https://doi.org/10.31014/aior.1992.02.03.149

[28] Anarfo, E.B., Agoba, A.M. and Abebreseh, R. (2017) Foreign Direct Investment in Ghana: The Role of Infrastructural Development and Natural Resources. African Development Review, 29, 575-588. https://doi.org/10.1111/1467-8268.12297

[29] Immurana, M. (2021) Does Population Health Influence FDI Inflows into Ghana? International Journal of Social Economics, 48, 334-347. https://doi.org/10.1108/IJSE-05-2020-0288

[30] Amoah, S.K. and Amoah, A.K. (2018) The Role of Small and Medium Enterprises (SMEs) to Employment in Ghana. International Journal of Business and Economics Research, 7, 151-157. https://doi.org/10.11648/j.ijber.20180705.14

[31] Liu, F., Park, K. and Whang, U. (2019) Organizational Capabilities, Export Growth and Job Creation: An Investigation of Korean SMEs. Sustainability, 11, 3986. https://doi.org/10.3390/su11143986

[32] Pham, Q.T. and Dinh, X.K. (2020) The Impacts of Organizational Culture on Knowledge Transferring in FDI Enterprises in Vietnam. International Journal of Innovation, 8, 392-411. https://doi.org/10.5585/iji.v8i3.16059

[33] Melane-Lavado, A. and Álvarez-Herranz, A. (2018) Different Ways to Access Knowledge for Sustainability-Oriented Innovation. The Effect of Foreign Direct Investment. Sustainability, 10, 4206. https://doi.org/10.3390/su10114206

[34] Howes, M., et al. (2017) Environmental Sustainability: A Case of Policy Implementation Failure? Sustainability, 9, 165. https://doi.org/10.3390/su9020165

[35] Sarkodie, S.A. and Strezov, V. (2018) Empirical Study of the Environmental Kuznets Curve and Environmental Sustainability Curve Hypothesis for Australia, China, Ghana and USA. Journal of Cleaner Production, 201, 98-110. https://doi.org/10.1016/j.jclepro.2018.08.039

[36] Havierniková, K. and Kordoš, M. (2019) Entrepreneurship and Sustainability Issues Selected Risks Perceived by SMES Related to Sustainable Entrepreneurship in Case of Engagement into Cluster Cooperation. Entrepreneurship and Sustainability Issues, 6, 1680-1693. https://doi.org/10.9770/jesi.2019.6.4(9)

[37] Giwa, B.A., George, E.O., Okodua, H. and Adediran, O.S. (2020) Empirical Analysis of the Effects of Foreign Direct Investment Inflows on Nigerian Real Economic Growth: Implications for Sustainable Development Goal-17. Cogent Social Sciences, 6, Article ID: 1727621. https://doi.org/10.1080/23311886.2020.1727621

[38] Ngo, Q.T. (2020) SMEs' In-House R\&D, Outsourced R\&D or Both: The Supply-Chain FDI Linkages and Technology Transfer. Uncertain Supply Chain Management, 8, 
821-830. https://doi.org/10.5267/j.uscm.2020.6.004

[39] Cuervo, J.C. and Cheong, K.U. (2017) Protecting the Survival of Local SMEs during Rapid Tourism Growth: Ongoing Lessons from Macao. Worldwide Hospitality and Tourism Themes, 9, 316-334. https://doi.org/10.1108/WHATT-02-2017-0009

[40] Bojnec, Š. and Tomšič, N. (2021) Corporate Sustainability and Enterprise Performance: The Mediating Effects of Internationalization and Networks. The International Journal of Productivity and Performance Management, 70, 21-39. https://doi.org/10.1108/IJPPM-05-2019-0226

[41] Bokpin, G.A. (2017) Foreign Direct Investment and Environmental Sustainability in Africa: The Role of Institutions and Governance. Research in International Business and Finance, 39, 239-247. https://doi.org/10.1016/j.ribaf.2016.07.038

[42] Munir, M., Jajja, M.S.S., Chatha, K.A. and Farooq, S. (2020) Supply Chain Risk Management and Operational Performance: The Enabling Role of Supply Chain Integration. International Journal of Production Economics, 227, Article ID: 107667. https://doi.org/10.1016/j.ijpe.2020.107667

[43] Amoako, S. and Insaidoo, M. (2021) Symmetric Impact of FDI on Energy Consumption: Evidence from Ghana. Energy, 223, Article ID: 120005.

https://doi.org/10.1016/j.energy.2021.120005

[44] Aust, V., Morais, A.I. and Pinto, I. (2020) How Does Foreign Direct Investment Contribute to Sustainable Development Goals? Evidence from African Countries. Journal of Cleaner Production, 245, Article ID: 118823. https://doi.org/10.1016/j.jclepro.2019.118823

[45] Kim, M.K., Park, J.H. and Paik, J.H. (2018) Factors Influencing Innovation Capability of Small and Medium-Sized Enterprises in Korean Manufacturing Sector: Facilitators, Barriers and Moderators. International Journal of Technology Management, 76, 214-235. https://doi.org/10.1504/IJTM.2018.10012461

[46] Frempong, J., Chai, J., Ampaw, E.M., Amofah, D.O. and Ansong, K.W. (2020) The Relationship among Customer Operant Resources, Online Value Co-Creation and Electronic-Word-of-Mouth in Solid Waste Management Marketing. Journal of Cleaner Production, 248, Article ID: 119228.

https://doi.org/10.1016/j.jclepro.2019.119228

[47] Chakraborty, S., Bhattacharya, S. and Dobrzykowski, D.D. (2014) Impact of Supply Chain Collaboration on Value Co-Creation and Firm Performance: A Healthcare Service Sector Perspective. Procedia Economics and Finance, 11, 676-694. https://doi.org/10.1016/S2212-5671(14)00233-0

[48] Mendoza-Silva, A. (2021) Innovation Capability: A Sociometric Approach. Social Networks, 64, 72-82. https://doi.org/10.1016/j.socnet.2020.08.004

[49] Konadu, R., Owusu-Agyei, S., Lartey, T.A., Danso, A., Adomako, S. and Amankwah-Amoah, J. (2020) CEOs' Reputation, Quality Management and Environmental Innovation: The Roles of Stakeholder Pressure and Resource Commitment. Business Strategy and the Environment, 29, 2310-2323. https://doi.org/10.1002/bse.2504

[50] Donbesuur, F., Ampong, G.O.A., Owusu-Yirenkyi, D. and Chu, I. (2020) Technological Innovation, Organizational Innovation and International Performance of SMEs: The Moderating Role of Domestic Institutional Environment. Technological Forecasting and Social Change, 161, Article ID: 120252. https://doi.org/10.1016/j.techfore.2020.120252

[51] Lusch, R.F. and Nambisam, S. (2015) Service Innovation on JSTOR. MIS Quarterly, 339, 155-176. https://www.jstor.org/stable/26628345?seq=1 https://doi.org/10.25300/MISQ/2015/39.1.07 
[52] Hein, A., Weking, J., Schreieck, M., Wiesche, M., Böhm, M. and Krcmar, H. (2019) Value Co-Creation Practices in Business-to-Business Platform Ecosystems. Electronic Markets, 29, 503-518. https://doi.org/10.1007/s12525-019-00337-y

[53] Ranjan, K.R. and Read, S. (2016) Value Co-Creation: Concept and Measurement. Journal of the Academy of Marketing Science, 44, 290-315.

https://doi.org/10.1007/s11747-014-0397-2 